\title{
Involvement of anti-tumor miR-124-3p and its targets in the pathogenesis of pancreatic ductal adenocarcinoma: direct regulation of ITGA3 and ITGB1 by miR-124-3p
}

\author{
Tetsuya Idichi' ${ }^{1}$, Naohiko Seki ${ }^{2}$, Hiroshi Kurahara ${ }^{1}$, Haruhi Fukuhisa $^{1}$, Hiroko Toda ${ }^{1}$, \\ Masataka Shimonosono ${ }^{1}$, Yasutaka Yamada ${ }^{2}$, Takayuki Arai ${ }^{2}$, Yoshiaki Kita ${ }^{1}$, Yuko \\ Kijima $^{1}$, Yuko Mataki ${ }^{1}$, Kosei Maemura ${ }^{1}$ and Shoji Natsugoe ${ }^{1}$ \\ ${ }^{1}$ Department of Digestive Surgery, Breast and Thyroid Surgery, Graduate School of Medical Sciences, Kagoshima University, \\ Kagoshima, Japan \\ ${ }^{2}$ Department of Functional Genomics, Chiba University Graduate School of Medicine, Chiba, Japan \\ Correspondence to: Naohiko Seki, email: naoseki@faculty.chiba-u.jp \\ Keywords: microRNA; miR-124-3p; ITGA3; ITGB 1; pancreatic ductal adenocarcinoma \\ Received: April 07, $2018 \quad$ Accepted: May 24, $2018 \quad$ Published: June 22, 2018 \\ Copyright: Idichi et al. This is an open-access article distributed under the terms of the Creative Commons Attribution License 3.0 \\ (CC BY 3.0), which permits unrestricted use, distribution, and reproduction in any medium, provided the original author and source \\ are credited.
}

\section{ABSTRACT}

MicroRNAs (miRNAs) are unique in that a single miRNA molecule regulates a vast number of RNA transcripts. Thus, aberrantly expressed miRNAs disrupt tightly controlled RNA networks in cancer cells. Our functional screening showed that expression of $m i R-124-3 p$ was downregulated in pancreatic ductal adenocarcinoma (PDAC) tissues. Here, we aimed to investigate the anti-tumor roles of $m i R-124-3 p$ in PDAC cells and to identify $m i R-124-3 p$-mediated oncogenic signaling in this disease. Ectopic expression of $m i R-124-3 p$ inhibited cancer cell migration and invasion in PDAC cells. Moreover, restoration of miR-124-3p suppressed oncogenic signaling, as demonstrated by reduced phosphorylation of focal adhesion kinase, AKT, and extracellular signal-regulated kinase, in PDAC cells. Our in silico database analyses and luciferase reporter assays showed that two cell-surface matrix receptors, integrin a3 (ITGA3) and integrin $\beta 1$ (ITGB1), were directly regulated by miR-124-3p in PDAC cells. Overexpression of ITGA3 and ITGB1 was confirmed in PDAC clinical specimens. Interestingly, a large number of cohort analyses from TCGA database showed that high expressions of ITGA3 and ITGB1 were significantly associated with poor prognosis of patients with PDAC. Knockdown of ITGA3 and ITGB1 by siRNAs markedly suppressed the migration and invasion abilities of PDAC cells. Moreover, downstream oncogenic signaling was inhibited by ectopic expression of miR-124-3p or knockdown of the two integrins. The discovery of anti-tumor miRNAs and miRNA-mediated oncogenic signaling may provide novel therapeutic targets for the treatment of PDAC.

\section{INTRODUCTION}

Among human malignant tumors, pancreatic ductal adenocarcinoma (PDAC) is the most difficult cancer to treat, and the 5-year survival rate of patients with PDAC is approximately $5 \%$ [1]. Owing to the lack of an effective diagnostic strategy, most patients with PDAC have local invasion or distant metastasis [2]. Only about $15 \%$ of patients are candidates for surgical resection, and the prognosis of patients with inoperable cancer is very poor [3]. Currently developed combination chemotherapies have a limited therapeutic impact on patients with advanced-stage disease [4]. Elucidation of the molecular mechanisms of lethal PDAC may lead to the development of novel therapeutic strategies.

MicroRNAs (miRNAs) are short noncoding RNAs that act as fine-tuners of the expression of protein-coding or noncoding genes [5]. In recent years, miRNAs have 
been shown to have both oncogenic and tumor-suppressive functions based on a variety of studies [6]. Currently developed bioinformatics approaches have indicated that a single miRNA can regulate many protein-coding RNAs; conversely, more than $60 \%$ of protein-coding genes in the human genome are controlled by miRNAs [7]. Therefore, aberrantly expressed miRNAs can disrupt entire networks of protein-coding or noncoding genes and affect the pathogenesis of human cancers.

Screening for dysregulated miRNAs in cancer cells is a critical first step to elucidating aberrantly expressed genes and proteins involved in cancer pathogenesis [8]. In PDAC, we have sequentially identified anti-tumor miRNAs using RNA sequencing-based miRNA expression signatures [9-11]. Our previous studies showed that clustered miRNAs, e.g., $m i R-375, m i R-216 a-5 p, m i R-216 a-3 p, m i R-$ $216 b-5 p, m i R-216 b-3 p$, and $m i R-217$, are significantly downregulated in PDAC tissues and act as anti-tumor miRNAs [9-11]. Moreover, overexpression of forkhead box Q1 (FOXQ1) and actin-binding protein anilin (ANLN) promote PDAC cell aggressiveness and are involved in PDAC pathogenesis [9, 10]. These findings suggested that analysis of novel cancer pathways mediated by antitumor miRNAs will provide new insights into the potential mechanisms underlying the aggressive course of PDAC.

In this study, we focused on miR-124-3p because our functional screening showed that restoration of $m i R$ 124-3p markedly inhibited oncogenic signaling in PDAC cells. Here, we aimed to investigate the anti-tumor roles of $m i R-124-3 p$ and to identify $m i R-124-3 p$-regulated novel oncogenic pathways in PDAC cells. The miR-124 family includes three members, miR-124-1, miR-124-2 and miR124-3 on different human chromosomal loci, 8q23.1, 8p12.1 and 20p13.33, respectively. The mature sequences of the three miR-124 family are exactly the same. Since their sequences are identical, we define the $m i R-124$ family as $m i R-124-3 p$ in this study. The gene structure of the miR-124 family and the chromosomal loci are shown in the Supplementary Figure 1.

Our present data showed that two cell-surface matrix receptors, integrin $\alpha 3$ (ITGA3) and integrin $\beta 1$ $(I T G B 1)$, were directly regulated by $m i R-124-3 p$ in PDAC cells. Recent studies demonstrated that dysregulation of the extracellular matrix (ECM) and integrin-mediated oncogenic signaling enhances cancer cell aggressiveness $[12,13]$. Thus, miR-124-3p-based approaches for PDAC can be used to identify potential targets for the development of new therapeutic strategies.

\section{RESULTS}

\section{Expression levels of $m i R-124-3 p$ in PDAC clinical specimens and cell lines}

Expression levels of miR-124-3p were validated using PDAC specimens (cancer tissues: $\mathrm{n}=30$ and normal pancreatic tissues: $\mathrm{n}=12$ ) and three PDAC cell lines (PANC-1, SW1990, and MIApaca-2). Backgrounds and clinicopathological characteristics of clinical samples are shown in Table 1A. Normal pancreatic tissues are shown in Table 1B.

The expression levels of miR-124-3p were significantly lower in PDAC tissues than in normal pancreatic tissues (normalized to $R N U 48 ; P=0.0029$, Figure 1A). However, for clinicopathological factors (i.e., age, sex, neoadjuvant chemotherapy, and recurrence), there were no significant differences in the expression of $m i R-124-3 p$.

Expression levels of three cancer cell lines were markedly low compared to normal pancreatic tissues (Figure 1A).

\section{Effects of ectopic expression of $m i R-124-3 p$ in PDAC cells}

To investigate the anti-tumor roles of $m i R-124-3 p$, we performed gain-of-function studies using transfection of PANC-1, SW1990, and MIApaca-2 cells.

In vitro assays demonstrated that cell proliferation, migration, and invasion were significantly inhibited in miR-124-3p mimic transfectants compared those in with mock or miR-control transfectants (each, $P<0.0001$; Figure 1B-1D), with particularly remarkable effects observed in migration and invasion assays. These results indicated that $m i R-124-3 p$ had anti-tumor roles in PDAC cells and could be categorized as an anti-tumor miRNA. We performed flow cytometric analyses to determine the number of apoptotic cells following restoration of $m i R$ 124-3p expression. The apoptotic cell numbers (apoptotic and early apoptotic cells) were increased in $m i R-124-$ $3 p$ expression than in mock or miR-control transfectant cells (Supplementary Figure 2A and 2B). We showed that cleaved PARP expression was detected in restoration of miR-124-3p expression (Supplementary Figure 2C).

\section{Blocking of oncogenic signaling by ectopic expression of $m i R-124-3 p$ in PDAC cells}

Next, we analyzed whether oncogenic signaling pathways were affected using gain-of-function $m i R-124-$ $3 p$ in PDAC cell lines. FAK, AKT, and ERK1/2 were selected as intracellular carcinogenic signaling molecules, and the phosphorylated state of each protein was evaluated by western blotting. The levels of phospho-FAK, phosphoAKT, and phospho-Erk1/2 were blocked by miR-124-3p expression in PDAC cells (Figure 1E).

\section{Identification of $m i R-124-3 p$-regulated oncogenic pathways and targets in PDAC cells}

To identify molecular oncogenic pathways and targets regulated by $m i R-124-3 p$ in PDAC cells, we 
Table 1A: Characteristics of patients with PDAC

\begin{tabular}{|c|c|c|c|}
\hline \multicolumn{3}{|c|}{ Pancreatic ductal adenocarcinoma (PDAC) } & \multirow[t]{2}{*}{$(\%)$} \\
\hline Total number & & 30 & \\
\hline Average age (range), years & & $65.8(42-79)$ & \\
\hline \multirow[t]{2}{*}{ Sex } & Male & 15 & $(50.0)$ \\
\hline & Female & 15 & $(50.0)$ \\
\hline \multirow[t]{5}{*}{$\mathrm{T}$ category } & pTis & 1 & $(3.3)$ \\
\hline & pT1 & 1 & $(3.3)$ \\
\hline & pT2 & 1 & $(3.3)$ \\
\hline & pT3 & 27 & $(90.1)$ \\
\hline & pT4 & 0 & $(0)$ \\
\hline \multirow[t]{2}{*}{$\mathrm{N}$ category } & 0 & 12 & $(40.0)$ \\
\hline & 1 & 18 & $(60.0)$ \\
\hline \multirow[t]{2}{*}{ M category } & 0 & 27 & $(90.0)$ \\
\hline & 1 & 3 & $(10.0)$ \\
\hline \multirow[t]{2}{*}{ Neoadjuvant chemotherapy } & $(-)$ & 13 & $(43.3)$ \\
\hline & $(+)$ & 17 & $(56.7)$ \\
\hline \multirow[t]{2}{*}{ Recurrence } & $(-)$ & 8 & $(26.7)$ \\
\hline & $(+)$ & 22 & $(73.3)$ \\
\hline
\end{tabular}

Table 1B: Characteristics of patients without PDAC

\begin{tabular}{|c|c|c|c|}
\hline \multicolumn{4}{|l|}{ Normal pancreatic tissue } \\
\hline Total number & & 12 & \\
\hline Average age (range), years & & $65.4(42-85)$ & \\
\hline \multirow[t]{2}{*}{ Sex } & Male & 5 & $(41.7)$ \\
\hline & Female & 7 & $(58.3)$ \\
\hline
\end{tabular}

applied a combination of in silico database analyses and gene expression analyses in PDAC clinical specimens. Our strategy is shown in Supplementary Figure 3.

Using the TargetScan database 7.1, we annotated 4,450 putative target genes having $m i R-124-3 p$ binding sites in their 3'- untranslated regions (UTRs). Gene expression data (GEO accession number: GSE15471) revealed that 2,148 genes were upregulated in PDAC clinical specimens (fold-change $\log _{2}>1.0$ ). Finally, we selected 435 genes that were putative oncogenic targets regulated by $m i R-124-3 p$ in PDAC cells.
We categorized 435 genes into existing molecular pathways using KEGG pathway analyses. The top 10 pathways contained 60 genes (Table 2A). We investigated the expression statuses of those 60 genes and the clinical significance of PDAC using the OncoLnc database (http:// www.oncolnc.org/). Kaplan-Meier survival curves showed that high expression of 15 genes was associated with poor prognosis in PDAC (Table 2B, Figure 2).

Furthermore, we provided a heatmap gene visualization and validated as a prognostic ability of these 15 genes (Figure 3). As shown in Figure 3, patients 
with high gene signature expressions $(Z$-score $>0)$ were significantly poor Overall Survival (OS) and Disease Free Survival (DFS) rate than those with low gene signature expressions (Z-score $\leq 0)(\mathrm{OS} ; P=0.0011$, DFS; $P=$ 0.0132 , Figure 3). Combination analysis of ITGA3 and $I T G B 1$ revealed that high expression of ITGA3/ITGB1 $(Z$-score $>0)$ was predicted significantly poor OS and DFS rate than those with low expression of ITGA3/ ITGB1 (Z-score $\leq 0)(\mathrm{OS} ; P=0.0037$, DFS; $P=0.0162$, Supplementary Figure 4$)$. In this study, we focused on ITGA3 and ITGB1.

\section{Overexpression of ITGA3 and ITGB1 in PDAC tissues and cell lines}

We evaluated the expression levels of ITGA3 and ITGB1 in PDAC tissues $(\mathrm{n}=30)$, normal pancreatic tissues $(\mathrm{n}=12)$, and three PDAC cell lines (PANC-1, SW1990, and MIApaca-2). The expression levels of ITGA3 and ITGB1 were significantly upregulated in PDAC tissues compared with normal pancreatic tissues (normalized to GUSB: $P=0.0004$, Figure 4A and $P=0.0006$, Figure 5A).

Negative correlations between $m i R-124-3 p$ expression and ITGA3 mRNA expression were analyzed by Spearman's rank test $(R=-0.496, P<0.0013$, Figure 4B). Additionally, negative correlations between $m i R$ 124-3p expression and ITGB1 mRNA expression were analyzed by Spearman's rank test $(\mathrm{R}=-0.543, P=0.0004$, Figure 5B).

\section{Direct regulation of $I T G A 3$ and $I T G B 1$ by $m i R$ - 124-3p in PDAC cells}

We performed qRT-PCR to validate miR-124$3 p$ repression of $I T G A 3$ mRNA expression in PDAC cell lines. Our studies revealed that ITGA3 mRNA was significantly reduced in $m i R-124-3 p$ mimic transfectants in comparison with mock or miR-control transfectants $(P<0.0001$, Figure 4C). Expression of ITGA3 protein was also repressed in the $m i R-124-3 p$ mimic transfectants (Figure 4D). In silico analysis using TargetScan database 7.1 showed that the 3 '-UTR of ITGA3 harbored one binding site for $m i R-124-3 p$ (Figure 4E). To determine whether ITGA3 mRNAs had functional target site, we performed dual luciferase reporter assays. Compared with the miR-control, luminescence intensity was significantly reduced by transfection with $m i R-124-3 p$ at $m i R-124-3 p$

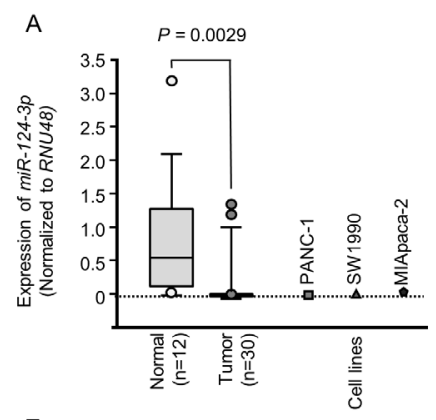

E



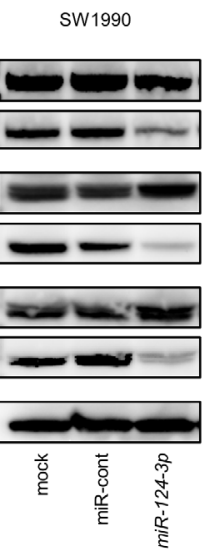

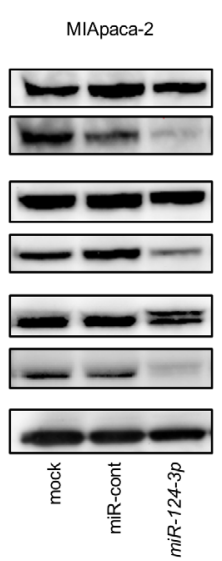

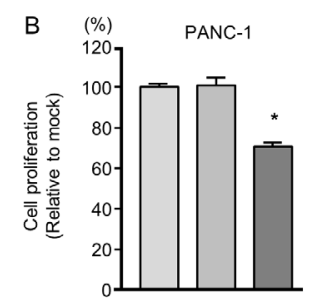
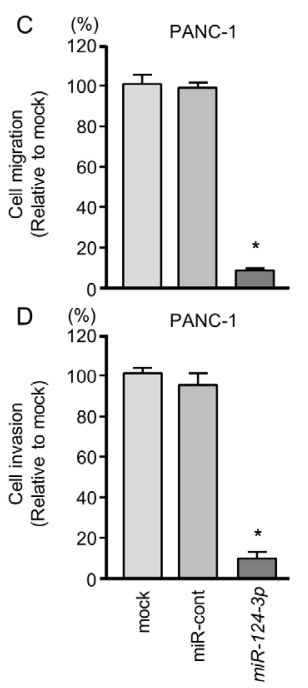
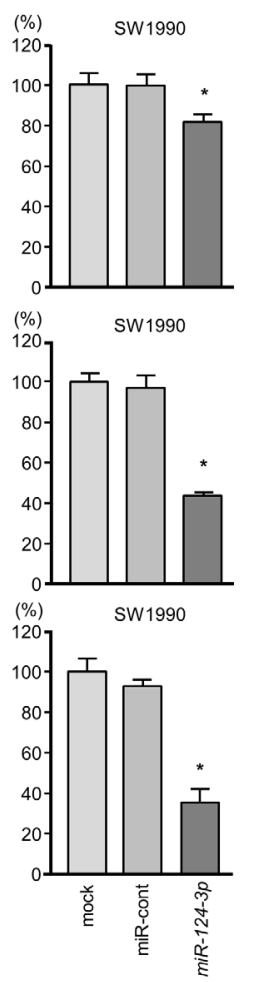
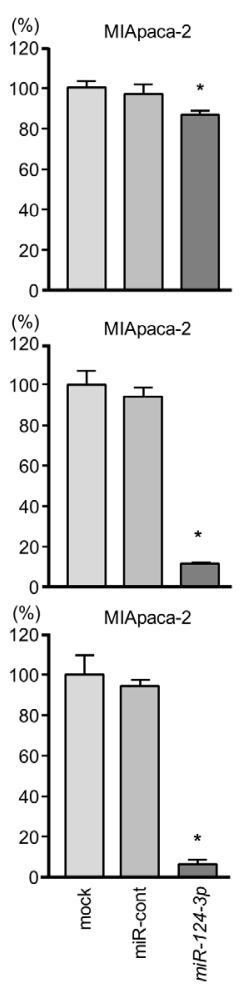

Figure 1: Anti-tumor functions of $m i R-124-3 p$ in PDAC cell lines and decreased phosphorylation of the components of oncogenic signaling pathways. (A) Expression levels of $m i R-124-3 p$ in PDAC clinical specimens and cell lines were determined by qRT-PCR. Data were normalized to RNU48 expression. ${ }^{*}, P<0.0001$. (B) Cell proliferation was determined by XTT assays $72 \mathrm{~h}$ after transfection with $10 \mathrm{nM}$ miR-124-3p. ${ }^{*}, P<0.0001$. (C) Cell migration activity was determined by migration assays. ${ }^{*}, P<0.0001$. (D) Cell invasion activity was determined using Matrigel invasion assays. ${ }^{*}, P<0.0001$. (E) Gain of function $m i R-124-3 p$ in PDAC cells reduced the phosphorylation of FAK, AKT, and Erk1/2. GAPDH was used as a loading control. 
Table 2A: Enriched KEGG pathways regulated by miR-124-3p on in silico analysis

\begin{tabular}{|c|c|c|c|c|}
\hline KEGG ID & Pathways & $P$ value & No. of genes & Genes \\
\hline Kegg:04512 & $\begin{array}{l}\text { ECM-receptor } \\
\text { interaction }\end{array}$ & 4.1783E-11 & 13 & $\begin{array}{l}\text { SDC1, ITGA1, SDC4, ITGA3, ITGA2, HSPG2, } \\
L A M C 1, C O L 4 A 1, T H B S 2, L A M C 2, I T G B 1, \\
\text { COL5A1, COL6A3 }\end{array}$ \\
\hline Kegg:05200 & Pathways in cancer & 1.0784E-09 & 21 & $\begin{array}{l}\text { E2F3, TGFBR1, MMP2, GLI3, ITGA3, ITGA2, } \\
\text { ETS1, AKT3, IL8, LAMC1, COL4A1, FZD2, } \\
\text { TGFB1, MITF, PDGFRB, LAMC2, ITGB1, RALA, } \\
\text { PLD1, CBL, CBLB }\end{array}$ \\
\hline Kegg:05145 & Toxoplasmosis & $3.5384 \mathrm{E}-06$ & 10 & $\begin{array}{l}\text { GNAI1, TLR4, AKT3, HSPA6, LAMC1, HLA-DPB1, } \\
\text { TGFB1, IL10RA, LAMC2, ITGB1 }\end{array}$ \\
\hline Kegg:04060 & $\begin{array}{l}\text { Cytokine-cytokine } \\
\text { receptor interaction }\end{array}$ & 5.5517E-06 & 14 & $\begin{array}{l}\text { IL7R, CXCL9, TGFBR1, IL8, CCL2, TGFB1, } \\
\text { IL10RA, PDGFRB, IFNAR2, CSF } 2 R B, \\
\text { TNFRSF11B, TNFSF4, LIF, TNFSF11 }\end{array}$ \\
\hline Kegg:04510 & Focal adhesion & 7.8047E-06 & 12 & $\begin{array}{l}\text { ITGA1, ITGA3, ITGA2, AKT3, LAMC1, COL } 4 A 1 \text {, } \\
\text { THBS2, PDGFRB, LAMC2,ITGB1, COL } 5 A 1, \\
\text { COL6A3 }\end{array}$ \\
\hline Kegg:04630 & $\begin{array}{l}\text { Jak-STAT signaling } \\
\text { pathway }\end{array}$ & $2.4297 \mathrm{E}-05$ & 10 & $\begin{array}{l}I L 7 R, A K T 3, J A K 3, S P R E D 1, I L 10 R A, I F N A R 2, \\
C S F 2 R B, C B L, L I F, C B L B\end{array}$ \\
\hline Kegg:04514 & $\begin{array}{l}\text { Cell adhesion } \\
\text { molecules (CAMs) }\end{array}$ & $2.8873 \mathrm{E}-05$ & 9 & $\begin{array}{l}C L D N 1, S D C 1, S D C 4, M P Z L 1, H L A-D P B 1, \\
C L D N 11, I T G B 1, V C A N, C L D N 4\end{array}$ \\
\hline Kegg:04810 & $\begin{array}{l}\text { Regulation of actin } \\
\text { cytoskeleton }\end{array}$ & 7.0689E-05 & 11 & $\begin{array}{l}\text { ITGA1, ARPC5, ARPC1B, ITGA3, MYH10, ITGA2, } \\
M S N, \text { GNA13, RRAS, PDGFRB, ITGB1 }\end{array}$ \\
\hline Kegg:04144 & Endocytosis & 0.00076292 & 9 & $\begin{array}{l}S H 3 K B P 1, T G F B R 1, H S P A 6, T G F B 1, R A B 31, \\
D A B 2, P L D 1, C B L, C B L B\end{array}$ \\
\hline Kegg:04010 & $\begin{array}{l}\text { MAPK signaling } \\
\text { pathway }\end{array}$ & 0.00596607 & 9 & $\begin{array}{l}\text { CACNA2D1, TGFBR1, AKT3, DUSP6, HSPA6, } \\
R R A S, T G F B 1, P D G F R B, M A P 3 K 8\end{array}$ \\
\hline
\end{tabular}

Table 2B: Candidate target genes regulated by miR-124-3p

\begin{tabular}{|c|c|c|c|c|c|c|}
\hline \multirow{2}{*}{$\begin{array}{l}\text { Entrez } \\
\text { gene }\end{array}$} & \multirow{2}{*}{$\begin{array}{c}\text { Gene } \\
\text { symbol }\end{array}$} & \multirow{2}{*}{ Gene name } & \multicolumn{2}{|c|}{ Target sites } & \multirow{2}{*}{$\begin{array}{l}\text { GEO data } \\
\text { FC(log2) }\end{array}$} & \multirow{2}{*}{$\begin{array}{l}{ }^{*} \text { TCGA_- } \\
\text { OncoLnc } \\
\text { P-value }\end{array}$} \\
\hline & & & $\begin{array}{l}\text { Conserved } \\
\text { sites }\end{array}$ & $\begin{array}{l}\text { Poorly } \\
\text { sites }\end{array}$ & & \\
\hline 3675 & $I T G A 3$ & $\begin{array}{l}\text { integrin, alpha } 3 \text { (antigen CD } 49 C \text {, alpha } 3 \\
\text { subunit of VLA-3 receptor) }\end{array}$ & 1 & 0 & 1.329 & 0.0004 \\
\hline 6237 & $R R A S$ & $\begin{array}{l}\text { related RAS viral (r-ras) oncogene } \\
\text { homolog }\end{array}$ & 1 & 0 & 1.147 & 0.0010 \\
\hline 3688 & $I T G B 1$ & $\begin{array}{l}\text { integrin, beta } 1 \text { (fibronectin receptor, } \\
\text { beta polypeptide, antigen CD29 includes } \\
\text { MDF2, MSK12) }\end{array}$ & 2 & 0 & 1.687 & 0.0024 \\
\hline 3673 & $I T G A 2$ & $\begin{array}{l}\text { integrin, alpha } 2(\mathrm{CD} 49 \mathrm{~B} \text {, alpha } 2 \text { subunit } \\
\text { of VLA-2 receptor) }\end{array}$ & 0 & 1 & 2.619 & 0.0031 \\
\hline 5898 & $R A L A$ & $\begin{array}{l}\text { v-ral simian leukemia viral oncogene } \\
\text { homolog A (ras related) }\end{array}$ & 1 & 0 & 1.028 & 0.0036 \\
\hline 6385 & $S D C 4$ & syndecan 4 & 1 & 0 & 1.030 & 0.0058 \\
\hline 6382 & $S D C 1$ & syndecan 1 & 0 & 1 & 1.384 & 0.0079 \\
\hline & & & & & & (Continued) \\
\hline
\end{tabular}




\begin{tabular}{|c|c|c|c|c|c|c|}
\hline \multirow{2}{*}{$\begin{array}{l}\text { Entrez } \\
\text { gene }\end{array}$} & \multirow{2}{*}{$\begin{array}{l}\text { Gene } \\
\text { symbol }\end{array}$} & \multirow{2}{*}{ Gene name } & \multicolumn{2}{|c|}{ Target sites } & \multirow{2}{*}{$\begin{array}{l}\text { GEO data } \\
\text { FC(log2) }\end{array}$} & \multirow{2}{*}{$\begin{array}{c}{ }^{*} \text { TCGA_- } \\
\text { OncoLnc } \\
\text { P-value }\end{array}$} \\
\hline & & & $\begin{array}{l}\text { Conserved } \\
\text { sites }\end{array}$ & $\begin{array}{l}\text { Poorly } \\
\text { sites }\end{array}$ & & \\
\hline 9076 & CLDN1 & claudin 1 & 0 & 5 & 1.892 & 0.0092 \\
\hline 1364 & CLDN4 & claudin 4 & 0 & 1 & 1.055 & 0.0097 \\
\hline 4283 & CXCL9 & chemokine (C-X-C motif) ligand 9 & 0 & 1 & 1.294 & 0.0121 \\
\hline 1848 & DUSP6 & dual specificity phosphatase 6 & 1 & 0 & 1.141 & 0.0137 \\
\hline 1293 & COL6A3 & collagen, type VI, alpha 3 & 0 & 1 & 2.749 & 0.0154 \\
\hline 30011 & $S H 3 K B P 1$ & SH3-domain kinase binding protein 1 & 1 & 0 & 1.652 & 0.0264 \\
\hline 2535 & FZD2 & frizzled family receptor 2 & 0 & 1 & 1.295 & 0.0349 \\
\hline 4478 & $M S N$ & moesin & 0 & 2 & 1.740 & 0.0389 \\
\hline 7058 & THBS2 & thrombospondin 2 & 1 & 1 & 3.986 & 0.0572 \\
\hline 7046 & TGFBR1 & transforming growth factor, beta receptor 1 & 1 & 0 & 1.567 & 0.0587 \\
\hline 3918 & $L A M C 2$ & laminin, gamma 2 & 0 & 1 & 2.761 & 0.0595 \\
\hline 2113 & ETS1 & $\begin{array}{l}\text { v-ets avian erythroblastosis virus E26 } \\
\text { oncogene homolog } 1\end{array}$ & 1 & 1 & 1.156 & 0.0674 \\
\hline 161742 & SPRED1 & $\begin{array}{l}\text { sprouty-related, EVH1 domain containing } \\
1\end{array}$ & 1 & 0 & 1.539 & 0.1010 \\
\hline 3587 & IL10RA & interleukin 10 receptor, alpha & 0 & 2 & 1.268 & 0.1380 \\
\hline 3718 & $J A K 3$ & Janus kinase 3 & 0 & 1 & 1.005 & 0.1670 \\
\hline 11031 & $R A B 31$ & RAB31, member RAS oncogene family & 0 & 1 & 2.855 & 0.1680 \\
\hline 4286 & MITF & $\begin{array}{l}\text { microphthalmia-associated transcription } \\
\text { factor }\end{array}$ & 2 & 0 & 1.117 & 0.2120 \\
\hline 3976 & LIF & leukemia inhibitory factor & 1 & 2 & 1.161 & 0.2140 \\
\hline 4628 & MYH10 & myosin, heavy chain 10 , non-muscle & 1 & 0 & 1.142 & 0.2170 \\
\hline 868 & $C B L B$ & $\begin{array}{l}\text { Cbl proto-oncogene } \mathrm{B}, \mathrm{E} 3 \text { ubiquitin } \\
\text { protein ligase }\end{array}$ & 0 & 1 & 1.434 & 0.2380 \\
\hline 8600 & TNFSF11 & $\begin{array}{l}\text { tumor necrosis factor (ligand) superfamily, } \\
\text { member } 11\end{array}$ & 1 & 0 & 1.412 & 0.2850 \\
\hline 6347 & CCL2 & chemokine (C-C motif) ligand 2 & 0 & 1 & 1.086 & 0.2990 \\
\hline 10000 & AKT3 & $\begin{array}{l}\text { v-akt murine thymoma viral oncogene } \\
\text { homolog } 3\end{array}$ & 2 & 0 & 1.023 & 0.3170 \\
\hline 3339 & $H S P G 2$ & heparan sulfate proteoglycan 2 & 0 & 1 & 1.080 & 0.3290 \\
\hline 1289 & COL5A1 & collagen, type V, alpha 1 & 0 & 1 & 3.496 & 0.3300 \\
\hline 10672 & GNA13 & $\begin{array}{l}\text { guanine nucleotide binding protein }(\mathrm{G} \\
\text { protein), alpha } 13\end{array}$ & 2 & 0 & 1.109 & 0.3300 \\
\hline 781 & $C A C N A 2 D 1$ & $\begin{array}{l}\text { calcium channel, voltage-dependent, alpha } \\
\text { 2/delta subunit } 1\end{array}$ & 1 & 0 & 1.619 & 0.3690 \\
\hline 1439 & $C S F 2 R B$ & $\begin{array}{l}\text { colony stimulating factor } 2 \text { receptor, beta, } \\
\text { low-affinity (granulocyte-macrophage) }\end{array}$ & 0 & 1 & 1.386 & 0.3940 \\
\hline 1462 & $V C A N$ & versican & 1 & 1 & 4.155 & 0.4380 \\
\hline
\end{tabular}




\begin{tabular}{|c|c|c|c|c|c|c|}
\hline \multirow{2}{*}{$\begin{array}{l}\text { Entrez } \\
\text { gene }\end{array}$} & \multirow{2}{*}{$\begin{array}{l}\text { Gene } \\
\text { symbol }\end{array}$} & \multirow{2}{*}{ Gene name } & \multicolumn{2}{|c|}{ Target sites } & \multirow{2}{*}{$\begin{array}{l}\text { GEO data } \\
\text { FC(log2) }\end{array}$} & \multirow{2}{*}{$\begin{array}{l}{ }^{*} \text { TCGA_- } \\
\text { OncoLnc } \\
\text { P-value }\end{array}$} \\
\hline & & & $\begin{array}{l}\text { Conserved } \\
\text { sites }\end{array}$ & $\begin{array}{l}\text { Poorly } \\
\text { sites }\end{array}$ & & \\
\hline 4313 & $M M P 2$ & $\begin{array}{l}\text { matrix metallopeptidase } 2 \text { (gelatinase } \\
\text { A, } 72 \mathrm{kDa} \text { gelatinase, } 72 \mathrm{kDa} \text { type IV } \\
\text { collagenase) }\end{array}$ & 0 & 2 & 2.531 & 0.4450 \\
\hline 3575 & $I L 7 R$ & interleukin 7 receptor & 0 & 1 & 1.444 & 0.4530 \\
\hline 3115 & $H L A-D P B 1$ & $\begin{array}{l}\text { major histocompatibility complex, class II, } \\
\text { DP beta } 1\end{array}$ & 0 & 1 & 1.232 & 0.4540 \\
\hline 7099 & TLR4 & toll-like receptor 4 & 0 & 3 & 1.095 & 0.5340 \\
\hline 867 & $C B L$ & $\begin{array}{l}\text { Cbl proto-oncogene, E3 ubiquitin protein } \\
\text { ligase }\end{array}$ & 3 & 2 & 1.058 & 0.5750 \\
\hline 1282 & COL4A1 & collagen, type IV, alpha 1 & 1 & 1 & 2.357 & 0.5830 \\
\hline 4982 & TNFRSF11B & $\begin{array}{l}\text { tumor necrosis factor receptor superfamily, } \\
\text { member } 11 \mathrm{~b}\end{array}$ & 0 & 1 & 1.697 & 0.6000 \\
\hline 3455 & IFNAR2 & $\begin{array}{l}\text { interferon (alpha, beta and omega) receptor } \\
2\end{array}$ & 0 & 1 & 1.072 & 0.6180 \\
\hline 3672 & ITGAI & integrin, alpha 1 & 0 & 2 & 1.561 & 0.6330 \\
\hline 2770 & GNAII & $\begin{array}{l}\text { guanine nucleotide binding protein } \\
\text { (G protein), alpha inhibiting activity } \\
\text { polypeptide } 1\end{array}$ & 1 & 0 & 1.210 & 0.6980 \\
\hline 10095 & $A R P C 1 B$ & $\begin{array}{l}\text { actin related protein } 2 / 3 \text { complex, subunit } \\
1 \mathrm{~B}, 41 \mathrm{kDa}\end{array}$ & 1 & 0 & 1.572 & 0.7020 \\
\hline 5010 & $C L D N 11$ & claudin 11 & 0 & 1 & 2.540 & 0.7350 \\
\hline 3915 & $L A M C 1$ & laminin, gamma 1 (formerly LAMB2) & 3 & 1 & 1.347 & 0.7430 \\
\hline 5337 & PLD1 & $\begin{array}{l}\text { phospholipase D1, phosphatidylcholine- } \\
\text { specific }\end{array}$ & 1 & 0 & 1.395 & 0.7630 \\
\hline 5159 & PDGFRB & $\begin{array}{l}\text { platelet-derived growth factor receptor, } \\
\text { beta polypeptide }\end{array}$ & 0 & 1 & 1.799 & 0.7750 \\
\hline 7292 & TNFSF4 & $\begin{array}{l}\text { tumor necrosis factor (ligand) superfamily, } \\
\text { member } 4\end{array}$ & 0 & 1 & 1.575 & 0.7930 \\
\hline 1601 & $D A B 2$ & $\begin{array}{l}\text { Dab, mitogen-responsive phosphoprotein, } \\
\text { homolog } 2 \text { (Drosophila) }\end{array}$ & 1 & 0 & 1.036 & 0.8810 \\
\hline 7040 & $T G F B 1$ & transforming growth factor, beta 1 & 0 & 1 & 1.423 & 0.8930 \\
\hline 9019 & MPZL1 & myelin protein zero-like 1 & 1 & 0 & 1.002 & 0.8940 \\
\hline 3576 & IL8 & interleukin 8 & 0 & 1 & 3.240 & 0.9220 \\
\hline 1326 & $M A P 3 K 8$ & $\begin{array}{l}\text { mitogen-activated protein kinase kinase } \\
\text { kinase } 8\end{array}$ & 0 & 1 & 1.352 & 0.9280 \\
\hline 10092 & $A R P C 5$ & $\begin{array}{l}\text { actin related protein } 2 / 3 \text { complex, subunit } \\
5,16 \mathrm{kDa}\end{array}$ & 0 & 1 & 1.038 & 0.9440 \\
\hline 3310 & HSPA6 & heat shock $70 \mathrm{kDa}$ protein 6 (HSP70B') & 0 & 1 & 1.347 & 0.9560 \\
\hline 2737 & GLI3 & GLI family zinc finger 3 & 1 & 0 & 1.343 & 0.9890 \\
\hline
\end{tabular}

*Kaplan-Meier analysis Log-rank.

P-value $<0.05$ Poor prognosis with a high expression. 
target sites, position 1160-1166 in the 3'-UTR of ITGA3 (Figure 4E).

Similarly, we performed qRT-PCR to validate $m i R$ 124-3p repression of ITGB1 mRNA expression in PDAC cell lines. Our studies revealed that ITGB1 mRNA was significantly reduced in $m i R-124-3 p$ mimic transfectants in comparison with mock or miR-control transfectants $(P<$ 0.0001 , Figure 5C). Expression of ITGB1 protein was also repressed in the $m i R-124-3 p$ mimic transfectants (Figure 5D). In silico analysis using TargetScan database 7.1 showed that the 3'-UTR of ITGB1 harbored two binding sites for $m i R-124-3 p$ (Figure 5E). To determine whether $I T G B 1$ mRNAs had functional target sites, we performed dual luciferase reporter assays. Compared with the miRcontrol, luminescence intensity was significantly reduced by transfection with $m i R-124-3 p$ at $m i R-124-3 p$ target sites, both position-1 236-242 in the 3'-UTR of ITGBI (Figure 5E, upper) and position-2 1095-1101 in the 3'UTR of ITGB1 (Figure 5E, lower)

\section{Effects of ITGA3 and ITGB1 knockdown in PDAC cells}

To validate the oncogenic functions of ITGA3 and $I T G B 1$ in PDAC cells, we performed knockdown assays using siRNAs (si-ITGA3 and si-ITGB1).
First, we evaluated the knockdown efficiency of si$I T G A 3$ and si-ITGB1 transfection in PDAC cell lines. In this study, we used two types of si-ITGA3 (si-ITGA3-1 and si-ITGA3-2) and si-ITGB1 (si-ITGB1-1 and si-ITGB1-2). Our data showed that all siRNAs effectively reduced ITGA3 and ITGB1 mRNA levels of expression in PDAC cell lines (Figures 6A and 7A). Furthermore, all siRNAs effectively reduced ITGA3 and ITGB1 protein levels of expression in PDAC cell lines (Figures 6B and 7B).

Moreover, cancer cell proliferation, migration, and invasion abilities were suppressed by knockdown of these genes (Figures 6C-6E and 7C-7E). The apoptotic cell numbers were increased in si-ITGA3 or si-ITGB1 transfectant cells than in mock or siRNA-control transfectant cells (Supplementary Figure 2A and 2B). We showed that cleaved PARP expression was detected in transfectant cells into si-ITGA3 or si-ITGB1 (Supplementary Figure 2C).

\section{Expression of ITGA3 and ITGB1 in PDAC clinical specimens and its clinical significance}

Next, we confirmed the expression of ITGA3 and ITGB1 proteins in PDAC clinical specimens using immunohistochemistry (IHC). In total, 30 PDAC specimens were evaluated. ITGA3 showed intracellular
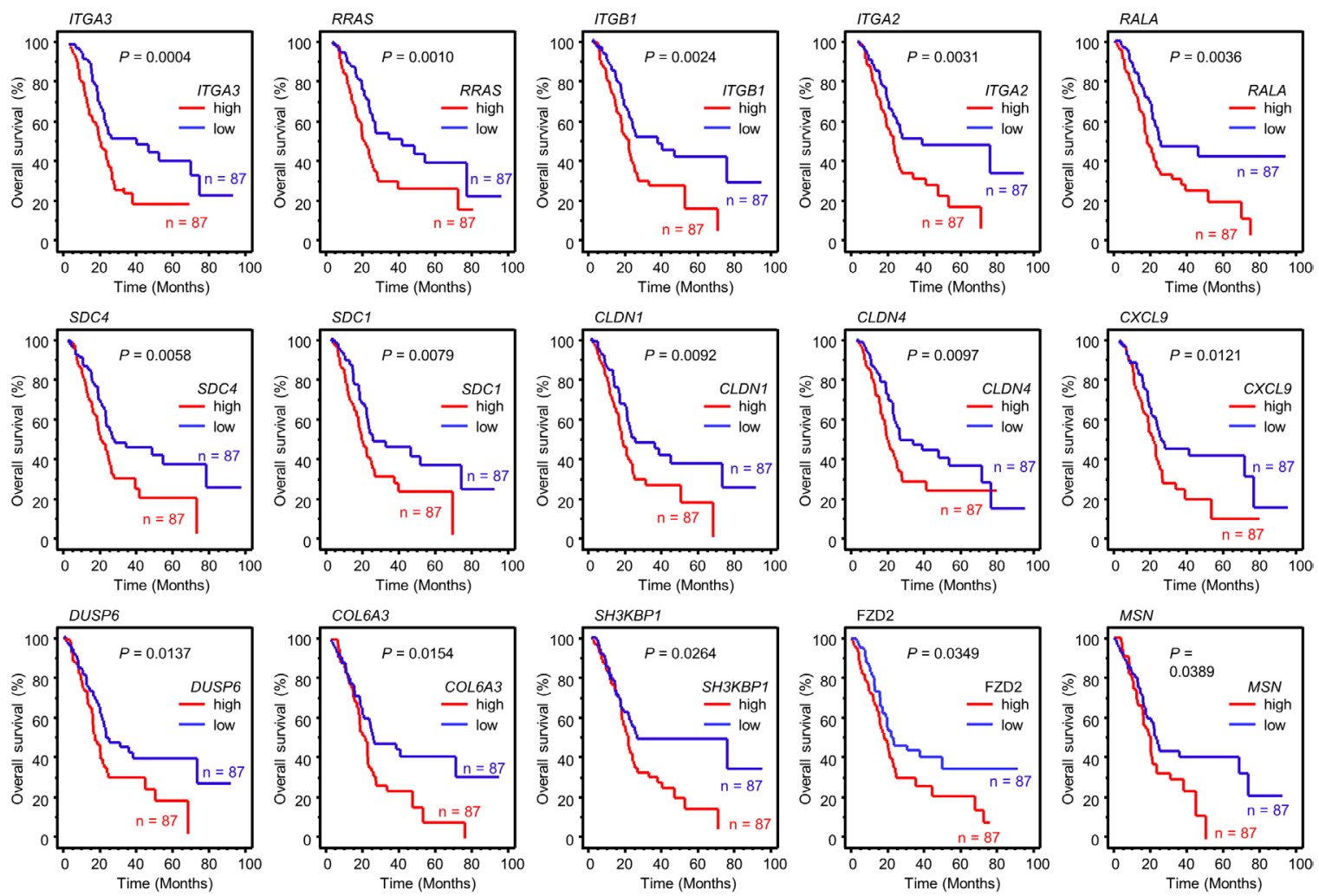

Figure 2: Kaplan-Meier analysis of $m i R-124-3 p$-regulated genes related to poor prognosis in PDAC. Kaplan-Meier plots of overall survival with log-rank tests between those with high and low miR-124-3p expression and expression of 15 genes in the PDAC TCGA database. 




Figure 3: Combination analysis with heatmap of 15 target genes related to poor prognosis in PDAC. Heatmap was created using analysis webcite "R2: Genomics Analysis and Visualization Platform (http://r2.amc.nl)". Z - score was evaluated by a combination of miR-124-3p final target genes based on TCGA datasets. High group (mRNA Z-score $>0$ ) and low group (mRNA Z-score $\leq 0)$ are displayed as Kaplan-Meier plots with log-rank tests.
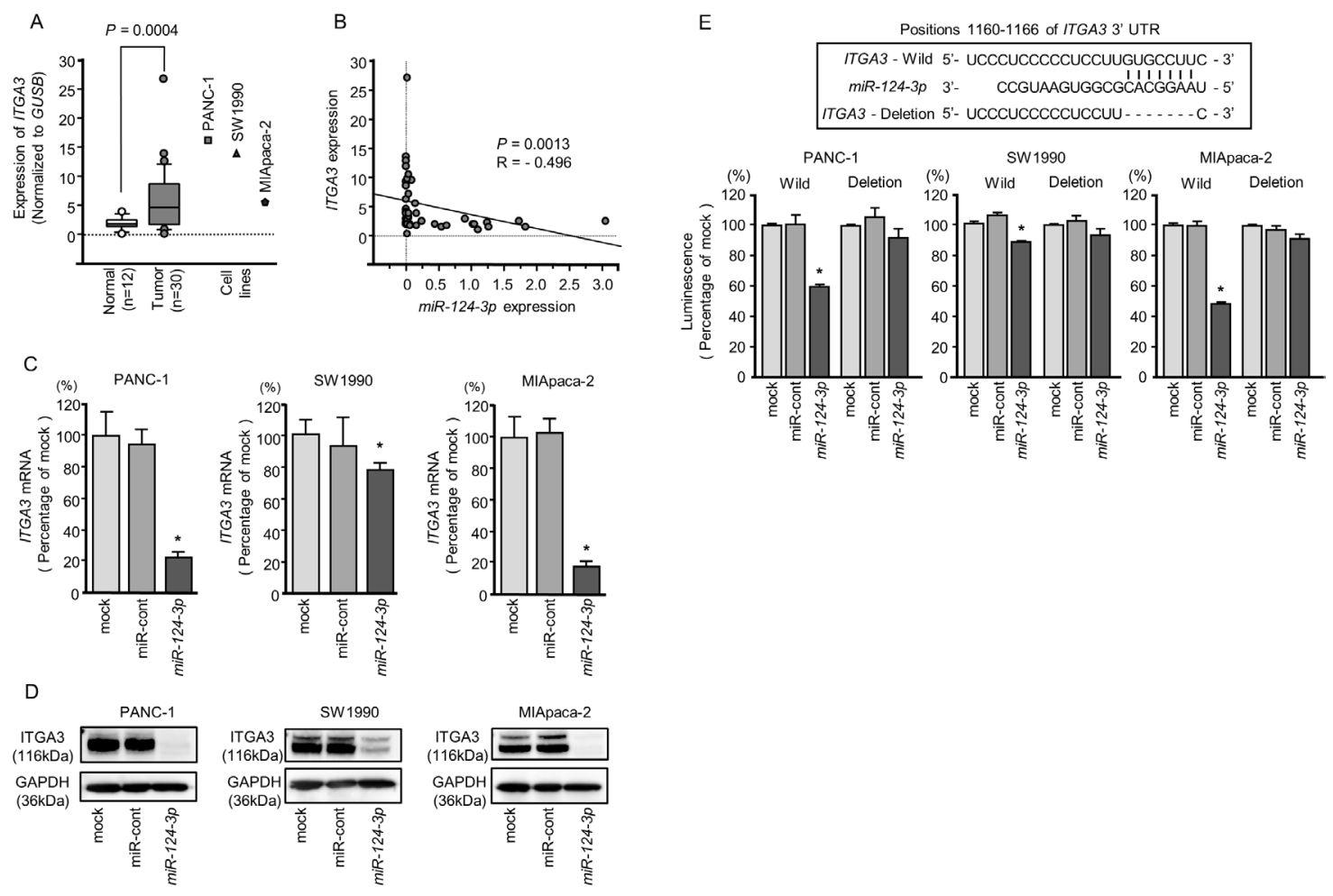

Figure 4: Direct regulation of ITGA3 by $\boldsymbol{m i R}-124-3 p$ in PDAC cell lines. (A) Expression levels of ITGA3 in PDAC clinical specimens and cell lines were determined by qRT-PCR. Data were normalized to GUSB expression. (B) Expression levels of ITGA3 and miR-124-3p were negatively correlated. (C) ITGA3 mRNA expression in PDAC cell lines was evaluated by qRT-PCR $72 \mathrm{~h}$ after transfection with $m i R-124-3 p$. GUSB was used as an internal control. * $P<0.0001$. (D) ITGA3 protein expression in PDAC cell lines was evaluated by western blot analysis $96 \mathrm{~h}$ after transfection with $m i R-124-3 p$. GAPDH was used as a loading control. (E) $m i R-124-3 p$ binding sites in the 3 '-UTR of ITGA3 mRNA. Dual luciferase reporter assays using vectors encoding the putative miR-124-3p (positions 1160-1166) target site of the ITGA3 3'-UTR for both wild-type and deleted regions. Normalized data were calculated as ratios of Renilla/firefly luciferase activities. ${ }^{*}, P<0.0001$. 
and membrane immunoreactivity in PDAC tissue, whereas ITGB1 showed medium membrane immunoreactivity in PDAC tissue (Figure 8A). For ITGA3-IHC staining, we categorized into "Weak" and "Strong" depending on the intensity of staining. (Figure 8B), OS and DFS were evaluated by Kaplan-Meier analysis, OS was shown that strong staining has poor prognosis with significant $(P=$ 0.0336 , Figure $8 C$ ). Details of clinicopathologic factors was shown in Supplementary Table 1. High ITGA3 expression was significantly associated with increased lymph node metastasis. In contrast, there were no significant relationships between ITGB1-IHC staining.

Finally, we examined the relationships between integrin expression and clinicopathological factors using TCGA database. There were no significant differences in terms of T, N, M, and TNM stages. However, high expression of ITGA3 was significantly associated with recurrence. In addition, DFS was significantly shorter in the high expression group (Supplementary Figure 5). In contrast, there were no significant relationships between ITGB1 expression and clinicopathological factors.

\section{DISCUSSION}

PDAC is the most lethal type of gastrointestinal cancer because it often does not cause any signs or symptoms in the early stages [1]. Moreover, there are no effective treatment strategies for patients with advanced stage PDAC, and the prognosis is extremely poor. Elucidation of the aggressive nature of PDAC based on current genomic approaches will provide important insights into novel treatment strategies for this disease. We have sequentially identified novel oncogenic RNA networks based on PDAC miRNA analyses [10]. Our recent studies showed that the miR-216 family and $m i R-217$ were downregulated in PDAC tissues and that these miRNAs acted as anti-tumor miRNAs by targeting FOXQ1 and $A N L N$, respectively [9, 10]. Additionally,
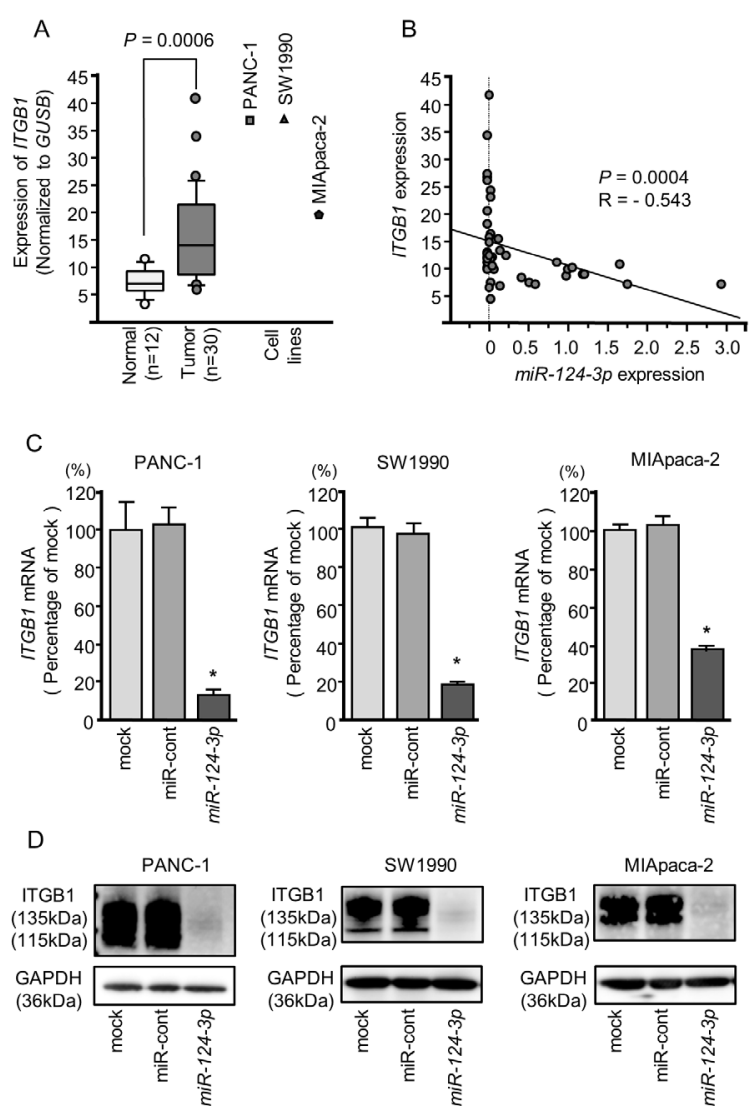

E
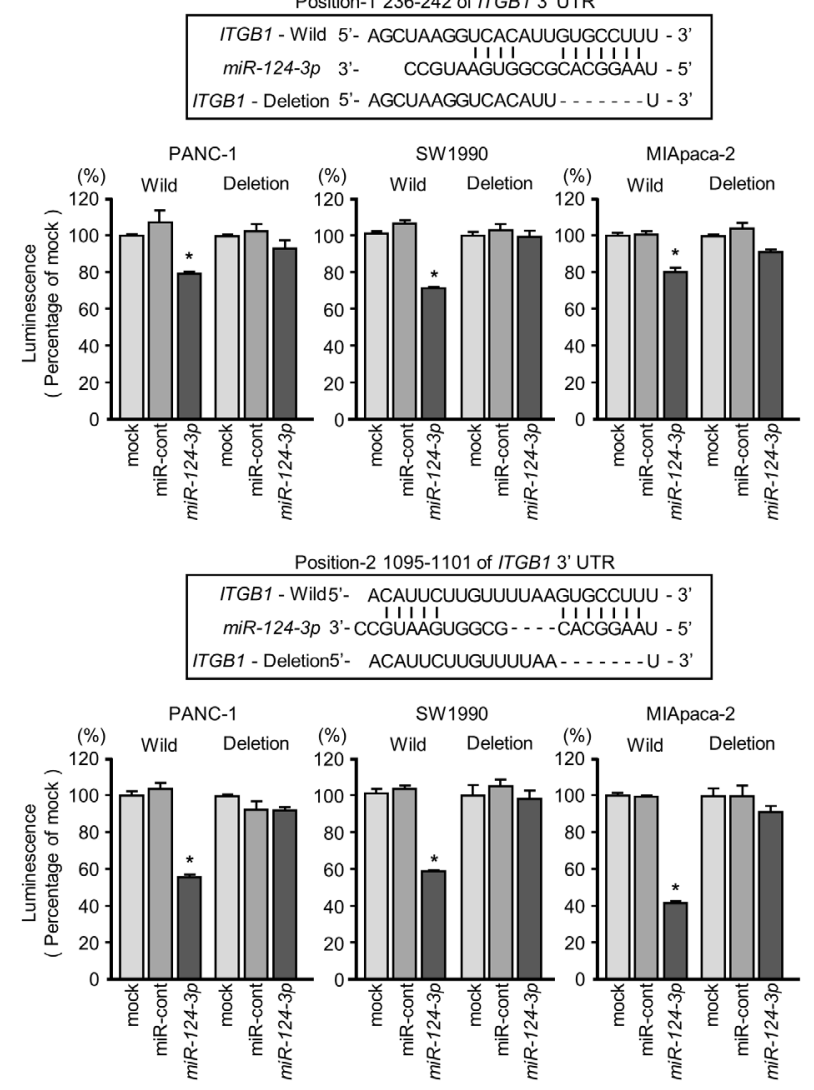

Figure 5: Direct regulation of ITGB1 by $\boldsymbol{m i R - 1 2 4 - 3 p}$ in PDAC cell lines. (A) Expression levels of ITGB1 in PDAC clinical specimens and cell lines were determined by qRT-PCR. Data were normalized to GUSB expression. (B) Expression levels of ITGB1 and $m i R-124-3 p$ were negatively correlated. (C) ITGB1 mRNA expression in PDAC cell lines was evaluated by qRT-PCR $72 \mathrm{~h}$ after transfection with $m i R-124-3 p$. GUSB was used as an internal control. ${ }^{*}, P<0.0001$. (D) ITGB1 protein expression in PDAC cell lines was evaluated by western blot analysis $96 \mathrm{~h}$ after transfection with $m i R-124-3 p$. GAPDH was used as a loading control. (E) $m i R-124-3 p$ binding sites in the 3'-UTR of ITGB1 mRNA. Dual luciferase reporter assays using vectors encoding the putative miR-124-3p (positions 236-242 and 1095-1101) target sites of the ITGB1 3'-UTR for both wild-type and deleted regions. Normalized data were calculated as ratios of Renillal firefly luciferase activities. ${ }^{*}, P<0.0001$. 



Figure 6: ITGA3 mRNA and protein expression after si-ITGA3 transfection and effects of ITGA3 silencing in PDAC cell lines. (A) ITGA3 mRNA expression in PDAC cell lines was evaluated by qRT-PCR $72 \mathrm{~h}$ after transfection with si-ITGA3-1 or siITGA3-2. GUSB was used as an internal control. (B) ITGA3 protein expression in PDAC cell lines was evaluated by western blot analysis $96 \mathrm{~h}$ after transfection with si-ITGA3-1 and si-ITGA3-2. GAPDH was used as a loading control. (C) Cell proliferation was determined using $\mathrm{XTT}$ assays $72 \mathrm{~h}$ after transfection with $10 \mathrm{nM}$ si-ITGA3-1 or si-ITGA3-2. ${ }^{*}, P<0.0001$. (D) Cell migration activity was determined using migration assays. ${ }^{*}, P<0.0001$. (E) Cell invasion activity was determined by Matrigel invasion assays. ${ }^{*}, P<0.0001$.


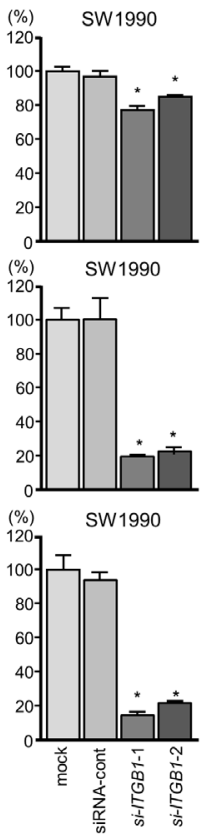
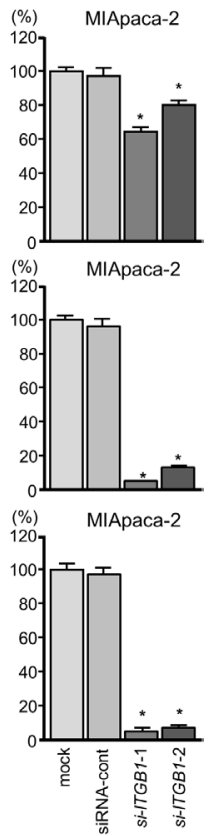

Figure 7: ITGB1 mRNA and protein expression after si-ITGB1 transfection and effects of ITGB1 silencing in PDAC cell lines. (A) ITGB1 mRNA expression in PDAC cell lines was evaluated by qRT-PCR $72 \mathrm{~h}$ after transfection with si-ITGB1-1 or siITGB1-2. GUSB was used as an internal control. (B) ITGB1 protein expression in PDAC cell lines was evaluated by western blot analysis $96 \mathrm{~h}$ after transfection with si-ITGB1-1 and si-ITGB1-2. GAPDH was used as a loading control. (C) Cell proliferation was determined with the XTT assays $72 \mathrm{~h}$ after transfection with $10 \mathrm{nM}$ si-ITGB1-1 or si-ITGB1-2. ${ }^{*}, P<0.0001$. (D) Cell migration activity was determined using migration assays. ${ }^{*}, P<0.0001$. (E) Cell invasion activity was determined by Matrigel invasion assays. ${ }^{*}, P<0.0001$. 
overexpression of FOXQ1 and $A N L N$ has been shown to promote cancer cell aggressiveness and is involved in PDAC pathogenesis $[9,10]$.

In this study, we focused on miR-124-3p because miRNA functional assays showed that ectopic expression of $m i R-124-3 p$ dramatically inhibited cancer cell migration and invasion by blocking several oncogenic signals. Previous studies have indicated that $m i R-124-3 p$ is a bona fide anti-tumor miRNA in several cancers, e.g., glioblastoma, esophageal cancer, hepatocellular carcinoma [14-16]. These studies showed that overexpression of $m i R-124-3 p$ inhibited cancer cells migration and invasion abilities through targeting several oncogenes, e.g., IQGAP1, LAMC1, ITGB1, STAT3, SP1 [14-16]. Other studies indicated that promoter region of $m i R-$ 124 genes (miR-124-1, miR-124-2 and $m i R-124-3)$ were methylated in cancer cells $[17,18]$. In PDAC cells, all member of miR-124 family were highly methylated in PDAC tissues compared with in non-cancerous tissues by pyrosequencing analysis [19]. Epigenetic modification of $m i R-124$ genes is greatly involved in silencing $m i R-124-3 p$ expression in several cancer cells. Our data confirmed that $m i R-124-3 p$ acted as an anti-tumor miRNA in PDAC cells, consistent with previous reports [19].

Next, we aimed to discover molecular networks controlled by anti-tumor $m i R-124 a-3 p$ in PDAC cells. To identify miR-124-3p-regulated networks, we applied in silico database analyses depending on a strategy we created independently [9-11]. Several pathways were found to be regulated by miR-124-3p in PDAC cells, including ECMreceptor interactions, pathways in cancer, cytokine-cytokine receptor interactions, focal adhesion, and actin cytoskeleton regulation. Finally, a total of 60 genes were identified as putative targets of $m i R-124-3 p$ in PDAC cells. We further analyzed the genes involved in these pathways and PDAC pathogenesis using TCGA database. Importantly, among 60 putative targets, high expression of 15 genes (ITGA3, RRAS, ITGB1, ITGA2, RALA, SDC4, SDC1, CLDN1, CLDN4, CXCL9, DUSP6, COL6A3, SH3KBP1, FZD2, and $M S N$ ) was significantly associated with poor prognosis in patients with PDAC. Interestingly, many of these genes were involved in ECM/integrin signaling. The ECM is an assembly of extracellular molecules secreted by cells and provides structural and biochemical support to surrounding cells $[20,21]$. Many studies have indicated that aberrant expression of ECM-related genes and activation of integrinmediated signaling enhance cancer cell migration and invasion abilities in several cancers [22, 23]. Moreover, dysregulation of these genes is involved in the pathogenesis of PDAC [24], and detailed analyses of the functional significance of these genes in PDAC cells are necessary.
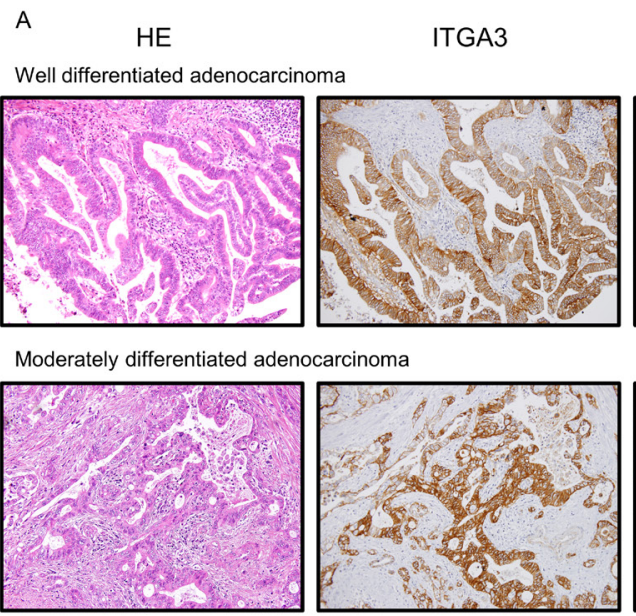

Poorly differentiated adenocarcinoma
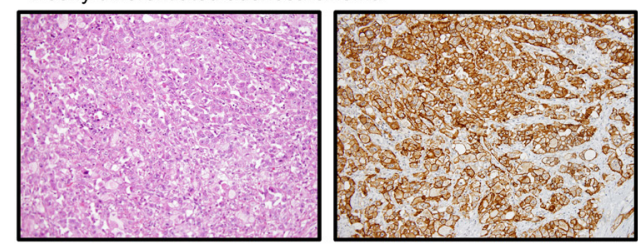

ITGB1
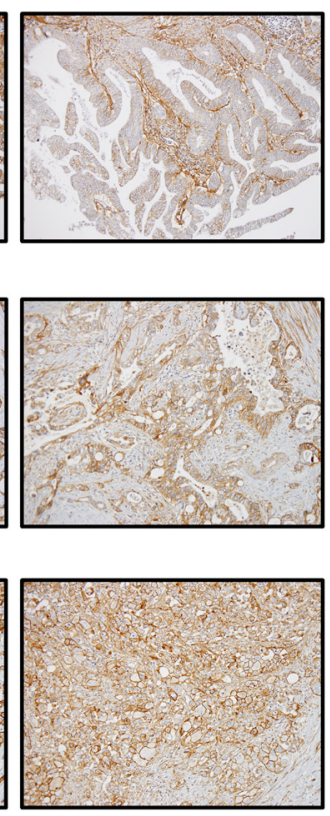

B
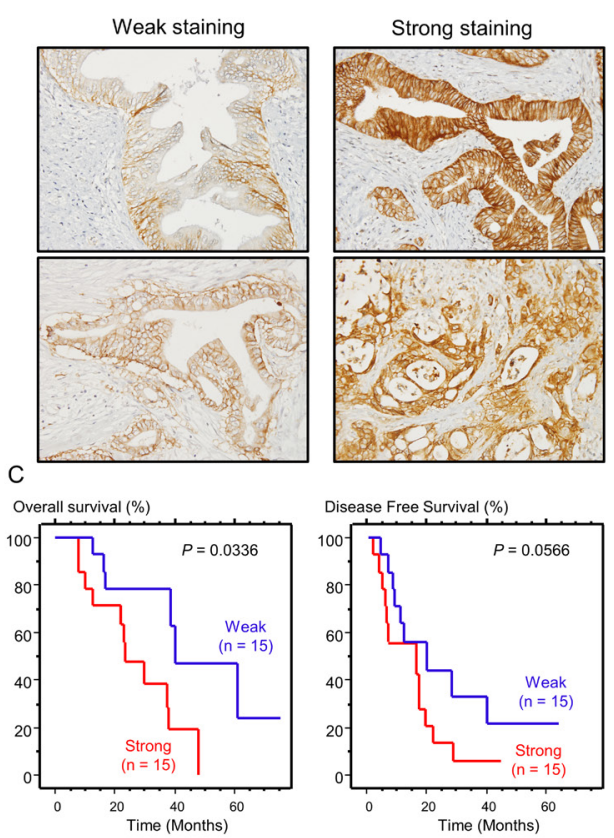

Figure 8: Expression levels of ITGA3/ITGB1 as determined by immunohistochemical staining in PDAC specimens. Immunohistochemical staining of ITGA3/ITGB1 in PDAC specimens. (A) All differentiated types of PDAC (well, moderately, poorly) showed immunoreactivity (left panel: hematoxylin-eosin staining, middle panel: ITGA3 staining, right panel: ITGB1 staining, original magnification, 200×). (B) Immunostaining of ITGA3 was classified by Weak (left panel) and Strong (right panel). The expression of ITGA3 was evaluated using high-power microscopy $(400 \times)$. (C) Kaplan-Meier curves for OS and DFS rates based on ITGA3 expression in 30 patients with PDAC. P-values were calculated using the log-rank test. 
Integrins are a family of transmembrane cell adhesion receptors that are responsible for mutual cellto-cell or cell-to-ECM, e.g., laminin, collagen, elastin, and fibronectin, communication [25]. Integrin receptors composed of specific two subunits ( $\alpha$ and $\beta$ ) and up to 24 distinct integrin receptors have been reported [26]. Overexpression of integrins and activation of integrinmediated oncogenic signaling have been reported in several cancers, affecting neighboring cancer cells or surrounding stromal cells and enhancing cancer cell aggressiveness and metastasis $[27,28]$. Our recent studies have shown that anti-tumor miRNAs, e.g., the miR-29 family, $m i R-150 \mathrm{~s}$, the $m i R-199$ family, $m i R-218$, and $m i R-223$, directly regulate several integrins, and these ligands and ectopic expression of these miRNAs have dramatically prevented cancer cell malignancy. $[12,13$, 29-31]

Our present data showed that both ITGA3 and $I T G B 1$ were directly regulated by anti-tumor $m i R-124-3 p$ in PDAC cells, and knockdown of these genes or ectopic expression of $m i R-124-3 p$ significantly blocked cancer cell aggressiveness. Moreover, overexpression of ITGA3 and $I T G B 1$ was involved in PDAC pathogenesis. ITGA3 and $I T G B 1$ form a specific type of integrin receptor (ITGA3/ITGB1), and dysregulation of ITGA3/ITGB1mediated signaling enhances cancer cell aggressiveness in several types of cancer [32-34]. ITGB1 can form 18 receptor heterodimers with various partners (integrin $\alpha$-subunits), and these receptors regulate numerous signaling pathways under both physiological and pathophysiological conditions [35]. Overexpression of $I T G B 1$ has been frequently observed in several cancers, including PDAC [36]. Therefore, blocking ITGB1, e.g., using small molecules or antibodies, may be an effective approach for the treatment of lethal PDAC [37]. Furthermore, our findings revealed that ITGA3 affected PDAC prognosis by altering recurrence and DFS. Antitumor miR-124-3p regulates important intracellular pathways for pancreatic cancer via dual ITGA3/ITGB1. Identification of novel anti-tumor miRNA-mediated RNA networks may contribute to the development of new therapeutic strategies. ITGA2 is also reported as a partner subunit of ITGB1 [38]. Our analysis showed that ITGA2 was identified as $m i R-124-3 p$ target and its expression was associated with poor prognosis of the patients with PDAC (Supplementary Figure 6). Previous studies showed that blocking of ITGA2 inhibited cancer cell aggressiveness [39]. Therefore, it is necessary to analyze the functional significance of ITGA2 in PDAC pathogenesis.

In conclusion, the anti-tumor roles of $m i R-124-3 p$ were achieved in PDAC cells through inhibition of several oncogenic signaling pathways. Oncogenic pathways and targets regulated by $m i R-124-3 p$ were involved in PDAC molecular pathogenesis. This is the first report demonstrating that the pivotal oncogenic receptors
$I T G A 3$ and ITGB1 were directly controlled by $m i R-124-$ $3 p$ in PDAC cells. Overexpression of these receptors was significantly associated with poor prognosis in patients with PDAC. Novel approaches based on anti-tumor miRNA-mediated oncogenic pathways and targets may contribute to the development of effective therapies for PDAC.

\section{MATERIALS AND METHODS}

\section{Clinical pancreatic specimens and PDAC cell lines}

In total, 30 PDAC specimens were obtained from patients who had undergone curative surgical resection at Kagoshima University Hospital from 1997 to 2016. Twelve normal pancreatic tissue specimens were collected from noncancerous regions. Frozen specimens were used for gene expression analysis, and paraffin sections were used for immunohistochemistry. The samples were staged according to the American Joint Committee on CancerUnion Internationale Contre le Cancer (UICC) TNM classification [40].

The present study was approved by the Institutional Review Board of Kagoshima University; prior written informed consent and approval was given by each patient.

Three human PDAC cell lines (PANC-1, SW1990, and MIApaca-2) obtained from RIKEN Cell Bank (Tsukuba, Ibaraki, Japan) and the American Type Culture Collection (Manassas, VA, USA) were used for this study.

RNA containing miRNAs was extracted using ISOGEN (NIPPON GENE, Toyama, Japan), according to the manufacturer's instructions.

\section{Quantitative real-time polymerase chain reaction (qRT-PCR)}

TaqMan qRT-PCR probes and primers were obtained from Thermo Fisher Scientific (Waltham, MA, USA) as follows: $m i R-124-3 p$ (product ID: 000446; Thermo), ITGA3 (product ID: Hs01076879_m1), ITGB1 (product ID: Hs01127536 m1) and ITGA2 (product ID: Hs00158127_m1). GUSB (product ID: Hs99999908_m1) and $R N U 48$ (product ID: 001006) were used as internal controls. The procedure for qRT-PCR was described in previous studies $[30,41]$.

\section{Transient transfection of mature miRNAs and small interfering RNAs (siRNAs) into cancer cells}

Pre-miR miRNA precursors and siRNAs were purchased from Thermo Fisher Scientific, as follows: miR-124-3p (product ID: PM 10245), negative control miRNA (product ID: AM 17111), two ITGA3 siRNAs (product IDs: HSS105529 and HSS179967), two ITGBI 
siRNAs (product IDs: HSS105559 and HSS105561), and negative control siRNA (product ID: D-00181010). Lipofectamine RNAiMAX and Lipofectamine 2000 (Thermo Fisher Scientific) were used for transfection into PDAC cell lines. The transfection efficiencies of miRNA in cancer cells were calculated as described in previous studies [42].

\section{Cell proliferation, migration, and invasion assays}

Cell proliferation was evaluated using a Cell Proliferation Kit II (Roche Applied Sciences, Penzberg, Germany). Cell migration was evaluated using BD Falcon Cell Culture Inserts (BD Biosciences, Franklin Lakes, NJ, USA), and cell invasion was evaluated using Corning BioCoat Matrigel Invasion Chambers (Corning, NY, USA). The protocols for functional assays were described previously $[11,13,30]$.

\section{Identification of miR-124-3p targets in PDAC cells}

To identify $m i R-124-3 p$ target genes, we performed a combination of genome-wide gene expression analyses and in silico database analyses as described in previous studies [9-11, 43].

We selected putative miRNA target genes using the Target Scan Human 7.1 database (http://www.targetscan. org/vert_71), GEO microarray database (https://www. ncbi.nlm.nih.gov/geo/; accession number GSE15471), to analyze gene expression levels in 36 PDAC samples versus 36 normal pancreatic tissue samples. Finally, The Cancer Genome Atlas (TCGA) database (https:// cancergenome.nih.gov/) was used for analysis of gene expression in PDAC. The strategy for selecting target genes in this study is shown in Supplementary Figure 3.

\section{TCGA database analysis of PDAC samples}

To investigate the clinical significance of the expression status of putative targets of $m i R-124-3 p$ in patients with PDAC, we analyzed TCGA datasets (https://gdc.nci.nih.gov/). A large amount of cohort data was retrieved from cBioPortal (http://www.cbioportal. org/) and OncoLnc (data downloaded on November 1, 2017). Detailed information on the method is described in a previous paper [44-45]. The Z-scores of target genes mRNA expression data and clinical sample information corresponding to PDAC patients were collected from cBioPortal. R2: Genomics Analysis and Visualization Platform (http://r2.amc.nl) was used to create a heatmap. Furthermore, Z- score was evaluated by a combination of each genes sets. High group (mRNA Z-score $>0$ ) and low group (mRNA Z-score $\leq 0$ ) were analyzed by Kaplan-Meier survival curves and log-rank statistics.

\section{Plasmid construction and dual-luciferase reporter assay}

Wild-type or deletion-type sequences of the 3'-UTR of ITGA3 and ITGB1 in miR-124-3p target sites were inserted into the psiCHECK-2 vector (C8021; Promega, Madison, WI, USA). The procedure for dual luciferase reporter assays was described previously $[11,12,42]$.

\section{Western blot analyses}

Antibodies used in the phosphorylation pathway were purchased from Cell Signaling Technology (Danvers, MA, USA) as follows: anti-focal adhesion kinase (FAK) antibodies (product ID: \#3285), anti-phospho-FAK antibodies (product ID: \#8556), anti-AKT antibodies (product ID: \#4691), anti-phospho-AKT antibodies (product ID: \#4060), anti-extracellular signal-regulated kinase (Erk) 1/2 antibodies (product ID: \#4695), and antiphospho-Erk1/2 antibodies (product ID: \#4370).

To investigate the expression of $m i R-124-3 p$ targets, anti-ITGA3 antibodies (HPA008572; Sigma-Aldrich, St. Louis, MO, USA) and anti-ITGB1 antibodies (\#9699; Cell Signaling Technology) were used for western blotting, PARP antibody (product ID: 9542; Cell Signaling Technology, Danvers, USA) was used for apoptosis assay, usage was according to each data sheet. Antiglyceraldehyde 3-phosphate dehydrogenase (GAPDH) antibodies (product ID: SAF6698; Wako, Osaka, Japan) were used as an internal loading control for western blotting. A detailed description of the western blotting procedure was published elsewhere [11].

\section{Immunohistochemistry}

Tissue sections were incubated overnight at $4{ }^{\circ} \mathrm{C}$ with anti-ITGA3 antibodies diluted 1:200 (HPA008572; SigmaAldrich, St. Louis, MO, USA) and anti-ITGB1 antibodies diluted 1:100 (\#9699; Cell Signaling Technology). The IHC score was calculated by judging the percentage of positively stained plasma membrane in cancer cells. The scores ranged from 1 to $3(1 ;<5 \%, 2 ; 5-50 \%$, and $3 ;>50 \%$ immunoreactive cells). Scores 1 and 2 were considered to indicate "weak" expression, while scores 3 indicated "Strong" expression of ITGA3.

\section{Statistical analysis}

Mann-Whitney U-tests were used for analysis between two groups, and Bonferroni-adjusted MannWhitney U-tests were used for analysis among multiple groups. Correlations between the expression of miR-124$3 p$ and ITGA3/ITGBI were evaluated using Spearman's rank tests. Overall survival (OS) and disease-free survival (DFS) after surgery were analyzed using Kaplan-Meier curves and evaluated with log-rank tests. We used Expert 
StatView software (version 5.0 SAS Institute Inc., Cary, $\mathrm{NC}$, USA) for these analyses.

\section{ACKNOWLEDGMENTS AND FUNDING}

We wish to thank the Joint Research Laboratory, Kagoshima University Graduate School of Medical and Dental Sciences, for the use of their facilities. The present study was supported by KAKENHI(C) grants 15K10801, 15K15501, 26293306, 18K09338, 18K08626, 18K08687 and $18 \mathrm{~K} 16322$.

\section{CONFLICTS OF INTEREST}

The authors declare no conflicts of interest.

\section{REFERENCES}

1. Kamisawa T, Wood LD, Itoi T, Takaori K. Pancreatic cancer. Lancet. 2016; 388:73-85. https://doi.org/10.1016/ S0140-6736(16)00141-0.

2. Hidalgo M. Pancreatic cancer. N Engl J Med. 2010; 362:1605-17. https://doi.org/10.1056/NEJMra0901557.

3. Gillen S, Schuster T, Meyer Zum Büschenfelde C, Friess $\mathrm{H}$, Kleeff J. Preoperative/neoadjuvant therapy in pancreatic cancer: a systematic review and meta-analysis of response and resection percentages. PLoS Med. 2010; 7:e1000267. https://doi.org/10.1371/journal.pmed.1000267.

4. Chrystoja CC, Diamandis EP, Brand R, Rückert F, Haun R, Molina R. Pancreatic cancer. Clin Chem. 2013; 59:41-46. https://doi.org/10.1373/clinchem.2012.196642.

5. Bartel DP. MicroRNAs: genomics, biogenesis, mechanism, and function. Cell. 2004; 116:281-97. https://doi. org/10.1016/S0092-8674(04)00045-5.

6. Su Y, Li X, Ji W, Sun B, Xu C, Li Z, Qian G, Su C. Small molecule with big role: MicroRNAs in cancer metastatic microenvironments. Cancer Lett. 2014; 344:147-56. https:// doi.org/10.1016/j.canlet.2013.10.024.

7. Zhang Y, Wang Z, Gemeinhart RA. Progress in microRNA delivery. J Control Release. 2013; 172:962-74. https://doi. org/10.1016/j.jconrel.2013.09.015.

8. Yonemori K, Kurahara H, Maemura K, Natsugoe S. MicroRNA in pancreatic cancer. J Hum Genet. J Hum Genet. 2017; 62:33-40. https://doi.org/10.1038/jhg.2016.59.

9. Idichi T, Seki N, Kurahara H, Yonemori K, Osako Y, Arai T, Okato A, Kita Y, Arigami T, Mataki Y, Kijima Y, Maemura K, Natsugoe S. Regulation of actin-binding protein ANLN by antitumor miR-217 inhibits cancer cell aggressiveness in pancreatic ductal adenocarcinoma. Oncotarget. 2017; 8:53180-93. https://doi.org/10.18632/oncotarget.18261.

10. Yonemori K, Seki N, Idichi T, Kurahara H, Osako Y, Koshizuka K, Arai T, Okato A, Kita Y, Arigami T, Mataki Y, Kijima Y, Maemura K, Natsugoe S. The microRNA expression signature of pancreatic ductal adenocarcinoma by RNA sequencing: anti-tumour functions of the microRNA-216 cluster. Oncotarget. 2017; 8:70097-115. https://doi.org/10.18632/oncotarget.19591.

11. Yonemori K, Seki N, Kurahara H, Osako Y, Idichi T, Arai T, Koshizuka K, Kita Y, Maemura K, Natsugoe S. ZFP36L2 promotes cancer cell aggressiveness and is regulated by antitumor microRNA-375 in pancreatic ductal adenocarcinoma. Cancer Sci. 2017; 108:124-35. https://doi. org/10.1111/cas.13119.

12. Kurozumi A, Goto Y, Matsushita R, Fukumoto I, Kato M, Nishikawa R, Sakamoto S, Enokida H, Nakagawa M, Ichikawa T, Seki N. Tumor-suppressive microRNA-223 inhibits cancer cell migration and invasion by targeting ITGA3/ITGB1 signaling in prostate cancer. Cancer Sci. 2016; 107:84-94. https://doi.org/10.1111/cas.12842.

13. Koshizuka K, Hanazawa T, Kikkawa N, Arai T, Okato A, Kurozumi A, Kato M, Katada K, Okamoto Y, Seki N. Regulation of ITGA3 by the anti-tumor miR-199 family inhibits cancer cell migration and invasion in head and neck cancer. Cancer Sci. 2017; 108:1681-92. https://doi. org/10.1111/cas.13298.

14. Fowler A, Thomson D, Giles K, Maleki S, Mreich E, Wheeler H, Leedman P, Biggs M, Cook R, Little N, Robinson B, McDonald K. miR-124a is frequently downregulated in glioblastoma and is involved in migration and invasion. Eur J Cancer. 2011; 47:953-63. https://doi. org/10.1016/j.ejca.2010.11.026.

15. Cheng Y, Li Y, Nian Y, Liu D, Dai F, Zhang J. STAT3 is involved in miR-124-mediated suppressive effects on esophageal cancer cells. BMC Cancer. 2015; 15:306. https://doi.org/10.1186/s12885-015-1303-0.

16. Cai QQ, Dong YW, Wang R, Qi B, Guo JX, Pan J, Liu YY, Zhang CY, Wu XZ. MiR-124 inhibits the migration and invasion of human hepatocellular carcinoma cells by suppressing integrin $\alpha \mathrm{V}$ expression. Sci Rep. 2017; 7:40733. https://doi.org/10.1038/srep40733.

17. Wilting SM, van Boerdonk RA, Henken FE, Meijer CJ, Diosdado B, Meijer GA, le Sage C, Agami R, Snijders PJ, Steenbergen RD. Methylation-mediated silencing and tumour suppressive function of hsa-miR-124 in cervical cancer. Mol Cancer. 2010; 9:167. https://doi. org/10.1186/1476-4598-9-167.

18. Xu L, Dai W, Li J, He L, Wang F, Xia Y, Chen K, Li S, Liu T, Lu J, Zhou Y, Wang Y, Guo C. Methylation-regulated miR-124-1 suppresses tumorigenesis in hepatocellular carcinoma by targeting CASC3. Oncotarget. 2016; 7:26027-41. https://doi.org/10.18632/oncotarget.8266.

19. Wang P, Chen L, Zhang J, Chen H, Fan J, Wang K, Luo J, Chen Z, Meng Z, Liu L. Methylation-mediated silencing of the miR-124 genes facilitates pancreatic cancer progression and metastasis by targeting Rac1. Oncogene. 2014; 33:51424. https://doi.org/10.1038/onc.2012.598.

20. Hynes RO. The extracellular matrix: not just pretty fibrils. Science. 2009; 326:1216-19. https://doi.org/10.1126/ science. 1176009 . 
21. Bonnans C, Chou J, Werb Z. Remodelling the extracellular matrix in development and disease. Nat Rev Mol Cell Biol. 2014; 15:786-801. https://doi.org/10.1038/nrm3904.

22. Gilcrease MZ. Integrin signaling in epithelial cells. Cancer Lett. 2007; 247:1-25. https://doi.org/10.1016/j. canlet.2006.03.031.

23. Ganguly KK, Pal S, Moulik S, Chatterjee A. Integrins and metastasis. Cell Adh Migr. 2013; 7:251-61. https://doi. org/10.4161/cam.23840.

24. Grzesiak JJ, Ho JC, Moossa AR, Bouvet M. The integrin-extracellular matrix axis in pancreatic cancer. Pancreas. 2007; 35:293-301. https://doi.org/10.1097/ mpa.0b013e31811f4526.

25. Takada Y, Ye X, Simon S. The integrins. Genome Biol. 2007; 8:215. https://doi.org/10.1186/gb-2007-8-5-215.

26. Hynes RO. Integrins: bidirectional, allosteric signaling machines. Cell. 2002; 110:673-87. https://doi.org/10.1016/ S0092-8674(02)00971-6.

27. Desgrosellier JS, Cheresh DA. Integrins in cancer: biological implications and therapeutic opportunities. Nat Rev Cancer. 2010; 10:9-22. https://doi.org/10.1038/ $\operatorname{nrc} 2748$

28. Seguin L, Desgrosellier JS, Weis SM, Cheresh DA. Integrins and cancer: regulators of cancer stemness, metastasis, and drug resistance. Trends Cell Biol. 2015; 25:234-40. https://doi.org/10.1016/j.tcb.2014.12.006.

29. Kinoshita T, Hanazawa T, Nohata N, Kikkawa N, Enokida $\mathrm{H}$, Yoshino H, Yamasaki T, Hidaka H, Nakagawa M, Okamoto Y, Seki N. Tumor suppressive microRNA-218 inhibits cancer cell migration and invasion through targeting laminin-332 in head and neck squamous cell carcinoma. Oncotarget. 2012; 3:1386-400. https://doi.org/10.18632/ oncotarget.709.

30. Kinoshita T, Nohata N, Hanazawa T, Kikkawa N, Yamamoto N, Yoshino H, Itesako T, Enokida H, Nakagawa M, Okamoto Y, Seki N. Tumour-suppressive microRNA29s inhibit cancer cell migration and invasion by targeting laminin-integrin signalling in head and neck squamous cell carcinoma. Br J Cancer. 2013; 109:2636-45. https://doi. org/10.1038/bjc.2013.607.

31. Koshizuka K, Nohata N, Hanazawa T, Kikkawa N, Arai T, Okato A, Fukumoto I, Katada K, Okamoto Y, Seki N. Deep sequencing-based microRNA expression signatures in head and neck squamous cell carcinoma: dual strands of pre-miR-150 as antitumor miRNAs. Oncotarget. 2017; 8:30288-304. https://doi.org/10.18632/oncotarget.16327.

32. Cagnet S, Faraldo MM, Kreft M, Sonnenberg A, Raymond K, Glukhova MA. Signaling events mediated by $\alpha 3 \beta 1$ integrin are essential for mammary tumorigenesis. Oncogene. 2014; 33:4286-95. https://doi.org/10.1038/ onc.2013.391.

33. Fu Y, Feng MX, Yu J, Ma MZ, Liu XJ, Li J, Yang XM, Wang YH, Zhang YL, Ao JP, Xue F, Qin W, Gu J, et al. DNA methylation-mediated silencing of matricellular protein dermatopontin promotes hepatocellular carcinoma metastasis by $\alpha 3 \beta 1$ integrin-Rho GTPase signaling. Oncotarget. 2014; 5:6701-15. https://doi.org/10.18632/ oncotarget.2239.

34. Varzavand A, Hacker W, Ma D, Gibson-Corley K, Hawayek M, Tayh OJ, Brown JA, Henry MD, Stipp CS. $\alpha 3 \beta 1$ Integrin Suppresses Prostate Cancer Metastasis via Regulation of the Hippo Pathway. Cancer Res. 2016; 76:6577-87. https://doi. org/10.1158/0008-5472.CAN-16-1483.

35. Chen MB, Lamar JM, Li R, Hynes RO, Kamm RD. Elucidation of the Roles of Tumor Integrin $\beta 1$ in the Extravasation Stage of the Metastasis Cascade. Cancer Res. 2016; 76:2513-24. https://doi.org/10.1158/0008-5472. CAN-15-1325.

36. Lu Y, Hu J, Sun W, Li S, Deng S, Li M. MiR-29c inhibits cell growth, invasion, and migration of pancreatic cancer by targeting ITGB1. Onco Targets Ther. 2015; 9:99-109.

37. Grzesiak JJ, Tran Cao HS, Burton DW, Kaushal S, Vargas F, Clopton P, Snyder CS, Deftos LJ, Hoffman RM, Bouvet M. Knockdown of the $\beta(1)$ integrin subunit reduces primary tumor growth and inhibits pancreatic cancer metastasis. Int J Cancer. 2011; 129:2905-15. https://doi.org/10.1002/ ijc. 25942 .

38. Kowalski-Chauvel A, Teissier G, Toulas C, CohenJonathan-Moyal E, Seva C. By modulating $\alpha 2 \beta 1$ integrin signalling, gastrin increases adhesion oF AGS-GR gastric cancer cells. Exp Cell Res. 2018; 362:498-503. https://doi. org/10.1016/j.yexcr.2017.12.014.

39. Lee CY, Marzan D, Lin G, Goodison S, Silletti S. a2 Integrin-Dependent Suppression of Pancreatic Adenocarcinoma Cell Invasion Involves Ectodomain Regulation of Kallikrein-Related Peptidase-5. J Oncol. 2011; 2011:365651. https://doi.org/10.1155/2011/365651.

40. Brierley JD, Gospodarowicz MK, Wittekind C. (2010). TNM Classification of Malignant Tumours, 7th Edition: Chichester, West Sussex, UK ; Hoboken, NJ: Wiley-Blackwell).

41. Nohata N, Hanazawa T, Kinoshita T, Inamine A, Kikkawa $\mathrm{N}$, Itesako $\mathrm{T}$, Yoshino $\mathrm{H}$, Enokida $\mathrm{H}$, Nakagawa M, Okamoto Y, Seki N. Tumour-suppressive microRNA-874 contributes to cell proliferation through targeting of histone deacetylase 1 in head and neck squamous cell carcinoma. Br J Cancer. 2013; 108:1648-58. https://doi.org/10.1038/ bjc.2013.122.

42. Yoshino H, Chiyomaru T, Enokida H, Kawakami K, Tatarano S, Nishiyama K, Nohata N, Seki N, Nakagawa M. The tumour-suppressive function of miR-1 and miR-133a targeting TAGLN2 in bladder cancer. Br J Cancer. 2011; 104:808-18. https://doi.org/10.1038/bjc.2011.23.

43. Osako Y, Seki N, Koshizuka K, Okato A, Idichi T, Arai T, Omoto I, Sasaki K, Uchikado Y, Kita Y, Kurahara H, Maemura K, Natsugoe S. Regulation of SPOCK1 by dual strands of pre-miR-150 inhibit cancer cell migration and invasion in esophageal squamous cell carcinoma. J 
Hum Genet. 2017; 62:935-44. https://doi.org/10.1038/ jhg.2017.69.

44. Gao J, Aksoy BA, Dogrusoz U, Dresdner G, Gross B, Sumer SO, Sun Y, Jacobsen A, Sinha R, Larsson E, Cerami E, Sander C, Schultz N. Integrative analysis of complex cancer genomics and clinical profiles using the
cBioPortal. Sci Signal. 2013; 6:pl1. https://doi.org/10.1126/ scisignal.2004088.

45. Anaya J. OncoLnc: linking TCGA survival data to mRNAs, miRNAs, and lncRNAs. PeerJ Computer Science. 2016; 2:e67. https://doi.org/10.7717/peerj-cs.67. 